\title{
Towards Cooling Tower Efficiency-An Energy Audit Approach
}

\author{
Alwin Long Su Weng ${ }^{1}$, Samson Mekbib Atnaw ${ }^{2, *}$, Roziah Binti Zailan ${ }^{2}$ and Muhamad Muhtazam Noor Din ${ }^{3}$ \\ ${ }^{1}$ Universiti Kebangsaan Malaysia LESTARI Institute for Environment \& Development \\ ${ }^{2}$ Universiti Malaysia Pahang, Faculty of Engineering Technology, Gambang, Pahang, 26300, Malaysia \\ ${ }^{3}$ Malaysian Green Technology Corporation, Green-Living-Energy Services
}

\begin{abstract}
This research studied the power generation trends from national grid and gas for a period of 4 years. Energy audit of critical systems like this is needful for optimal energy utilization. An energy audit was carried out on 6 industrial cooloing towers and their annual operating cost calculated. Variable speed drive suggested was installed and corresponding annual energy savings of 114,900 kWh/year cost saving of RM30,000 was achieved at a case study plant located in Malaysia. Cooling towers with smart systems was recommended for higher energy savings.
\end{abstract}

\section{Introduction}

Manufacturing industries comprises of many energyconsuming systems and subsystems. To minimize the industry's energy requirements, these systems must operate at optimal overall efficiency. This is practically achievable when such device possess the capability to track load changes in real time [1]. Electricity supply from the mains have been unable to keep pace with the increasing industrial development. The aftermath of this has led to increased concentration of greenhouse gases from anthropogenic actions especially emissions from manufacturing industries [2,9]. There is therefore an urgent need for reduced energy consumption from cooling systems making them function at optimal level $[3,9,10-11]$. Reducing excessive energy consumption in power drives in turn decreases the lifecycle costs [4].

Cooling towers forms an integral part of the thermodynamic system in petrochemical industries, mining, manufacturing industries not leaving out residential houses $[1,5]$. Mechanical forced draft cooling towers with counter-flow systems possess electric motor drives removes heat from cooling water by adding sensible heat from the heated fluid to air up to saturated condition. The cooling rate of mechanical draft cooling towers largely depends on the fan diameter and its speed of operation $[7,8]$. The speed of rotation of fans in turn depends on the specification of the motor drive. Cooling in this system is a function of the wet bulb temperature due to psychometric characteristics exhibited by the mixture of fluid and gas.

Shown in Fig. 1 (a) and (b) are two views of a cooling tower equipped with four units of $7.5 \mathrm{~kW}$ fans for each cell. A total of 6 fans were running during survey with 4-2 and 3-3 combination on separate occasions. At low production time, only four fans will be in operation. Each Cooling Tower at the point of audit was drawing approximately 43.2 amperes with three cells in operation with all fans at functional conditions.

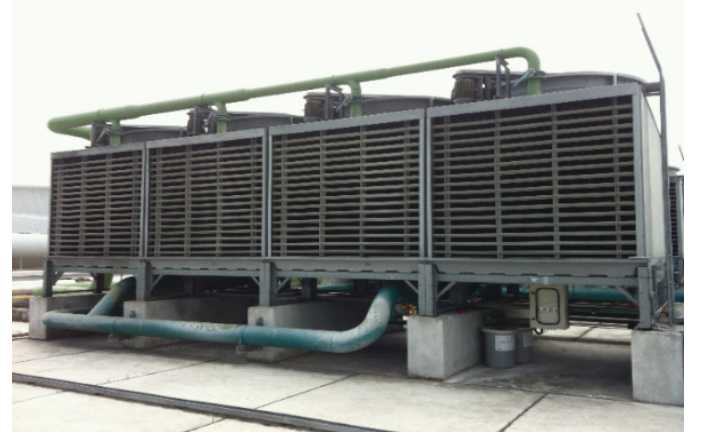

(a)

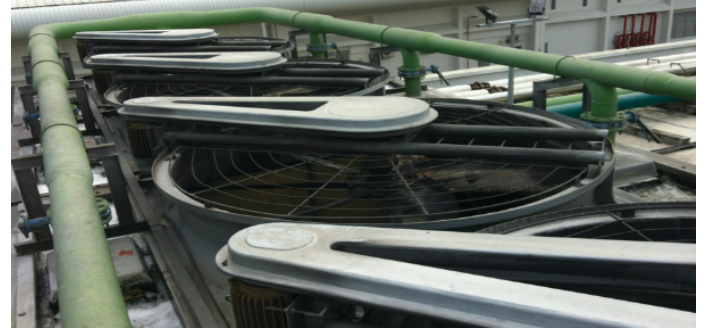

(b)

Fig. 1. (a) and (b) Vertical draft cooling tower

Corresponding author: mekbibsams@ump.edu.my 


\section{Materials and Methods}

For the success of a new method, it is needful to determine the present operating conditions. To perform this, annual cost of operations at system functionality of 24 hours and 300 days per year was calculated. The trend of energy generation for a period of 4 years (2012-2015) was studied. Energy from the national grid and the gas as a fossil fuel alternative was studied. Electricity cost over the period of study was also considered and related to energy loss per kilowatt.

\subsection{Energy savings at varying temperature, variable speed drive (VSD)}

Energy savings through variable speed drive (VSD) was recommended on the cooling tower fans. Installation of a temperature sensor in the basin to modulate the speed to run efficiently according to process demand. Under all operational procedures, the VSD will be set to provide sufficient cooling to the system. No optimal set-point is provided as the fan speed will be controlled to provide optimal cooling below $32^{\circ} \mathrm{C}$ as stated in best manufacturing benchmarking data. The system was subjected to varying wet bulb temperatures and future projections of energy consumption was calculated as

\begin{tabular}{|l|l|l|l|l|}
\hline $\begin{array}{l}\text { Return } \\
\text { Temperat } \\
\text { ure } \\
\text { caused } \\
\text { by } \\
\text { productio } \\
\text { n \& wet- } \\
\text { bulb } \\
\left({ }^{\circ} \mathrm{C}\right)\end{array}$ & $\begin{array}{l}\text { Total } \\
\text { Fan } \\
\text { ine } \\
(\mathrm{kW})\end{array}$ & $\begin{array}{l}\text { Estimate } \\
\mathrm{d} \text { Speed } \\
(\mathrm{Hz})\end{array}$ & $\begin{array}{l}\text { Running } \\
(\%)\end{array}$ & $\begin{array}{l}\text { Future } \\
\text { Running } \\
(\mathrm{kW})\end{array}$ \\
\hline 36 & 45 & 47 & 94 & \\
\hline 35 & 45 & 42 & 84 & 26.7 \\
\hline 34 & 45 & 40 & 80 & 23.0 \\
\hline 32 & 45 & 37 & 74 & 18.2 \\
\hline 31 & 45 & 35 & 70 & 15.4 \\
\hline
\end{tabular}

shown in Table 1.

Table 1. Potential savings on temperature fluctuation

\subsection{Process performance evaluation}

On implementing the suggested modifications both to the process and a process performance evaluation based on two models were performed on the system. Energy savings was verified after implementation: using the International Performance Measurement and Verification Protocol (IPMVP) and the Energy Efficiency Index (EEI).

Energy savings were determined after project completion by short-term or continuous measurements taken throughout the term of the contract at the device or system level; performance and operations factors were monitored. Savings were calculated with engineering calculations using metered data. Cost of this option is dependent on number and type of systems measured and the term of analysis metering; typically $3-10 \%$ of project construction cost of items subject to $M \& V$. Variable speed drive and controls were applied in the process to a motor to adjust fan speed.

Electric power was measured with a kilowatt meter installed on the electrical supply to the motor, which reads the power every minute. In the baseline period this meter was in place for a week to verify constant loading. The meter was in place throughout the reporting period to track variations in power use.

\section{Results and Discussion}

\subsection{Costs of operations}

Operating the cooling tower for 24 hours a day and 300 days in a year, the following breakdown remains valid; Average Power Consumption for each fan $=14$ ampere Average Power Consumption for each fan $=7.5 \mathrm{~kW}$ Total units running per time $=\quad 6$ units Total Power Consumption for the system $=45 \mathrm{~kW}$ Average Cost of Electricity $=\quad 0.30 \mathrm{RM} / \mathrm{kWh}$ Annual Total Energy Consumption $=302,400 \mathrm{kWh}$ Annual Cost $=$ $114,900 \mathrm{RM}$ Carbon Emission $=\quad 206$ Tonnes of $\mathrm{CO}_{2}$

The carbon emission was estimated using a factor based on the total electricity consumption. Shown in Fig. 2 is the electricity tariff within the period of study. Here exist an increase from the base period to the period of the study termination. Significant financial loss is incurred for a kilowatt of energy wasted per year. The plot shown in Fig. 3 reveals an increasing trend of the cost of gas. Production systems running on fossil fuels tend to accrue more operational cost compared with the national grid as the national grid supply is assumed cheaper than the fossil fuel. A kilowatt waste in energy generated therefore amounts to a fortune.

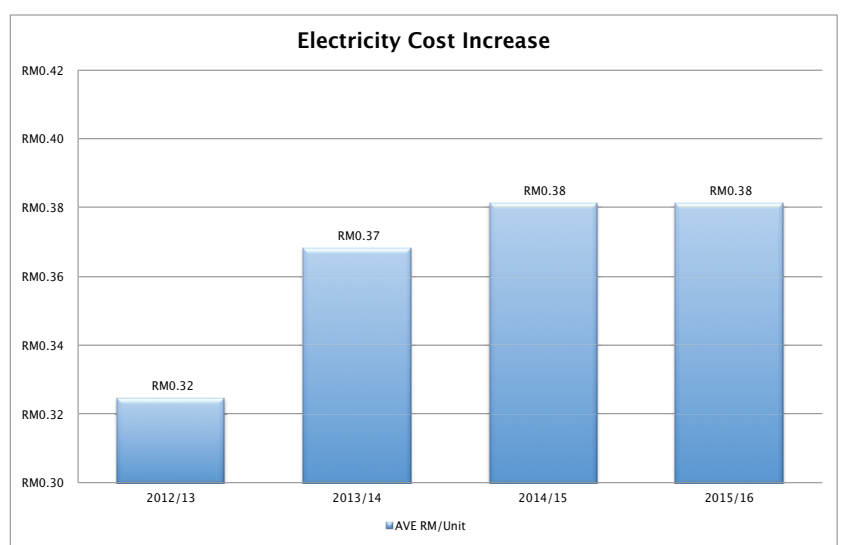

Fig. 2. Electricity cost from 2012-2015 


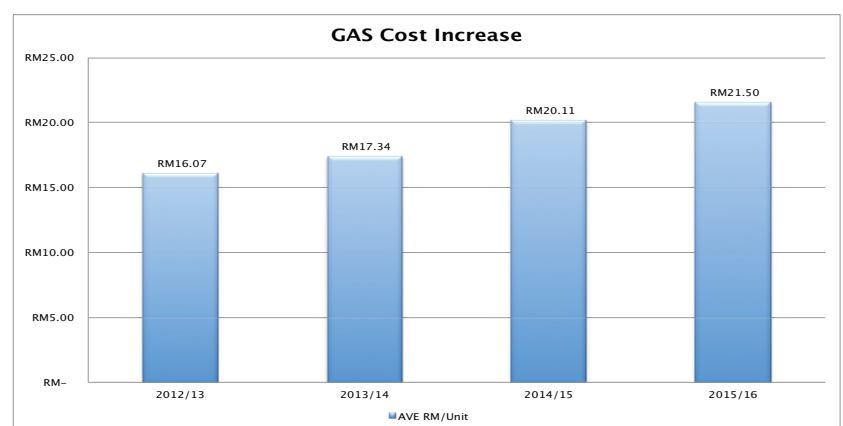

Fig. 3. Gas cost from 2012-2015

\subsection{Monthly monitoring and verification using EEI (Factored data)}

Electricity production followed a sinusoidal trend (Fig. 4). A decreasing trend is observed from 2012 to 2015 in power generation. Power generated in 2015 appears to be the least amount the years. Optimal utilization of the power generated is needful for manufacturing industries not only to minimize production cost but also satisfy energy demand.

Energy efficiency index (EEI) reveals energy cost against production increased by $1.8 \%$ and $2.2 \%$ over the 3 years period and energy Consumption against production improved by $9.3 \%$ and $2.9 \%$ over the 3 years period. Energy cost increased by an average of $15 \%$ for electricity and $34 \%$ on gas making cost of production (RM/ton) increase inevitably year-on-year. Production efficiency shows improvement by $11.9 \%$.

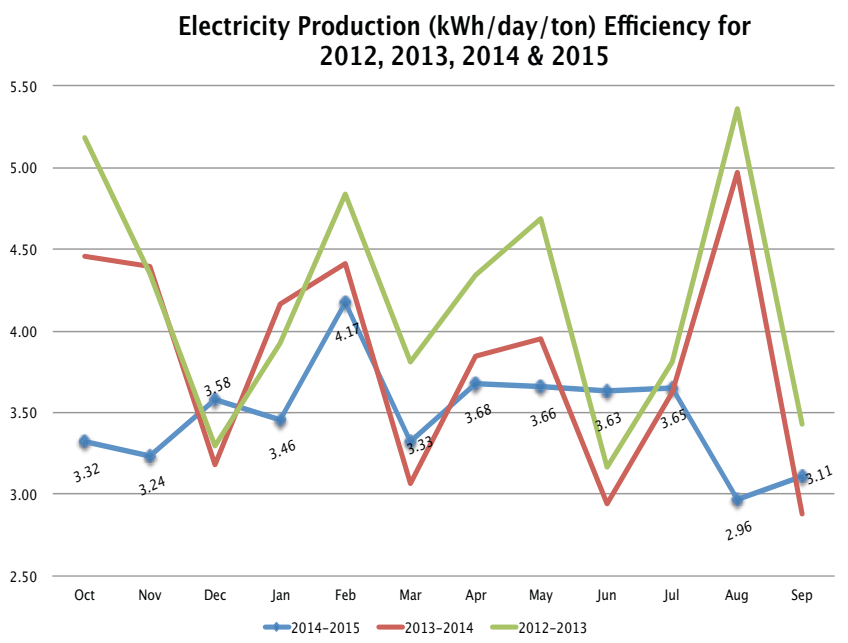

Fig. 4. Electricity production efficiency from 20122015

In the reverse, gas production increased from 2012 to 2015 (Fig. 5). This accounts for the fall in electricity production from the mains as manufacturing processes need to run on alternative energy source which fossil fuel is more reliable. Increase in the gas production is concomitant to increased environmental pollution among other environmental impact it has. Energy generated should therefore be optimally utilized.

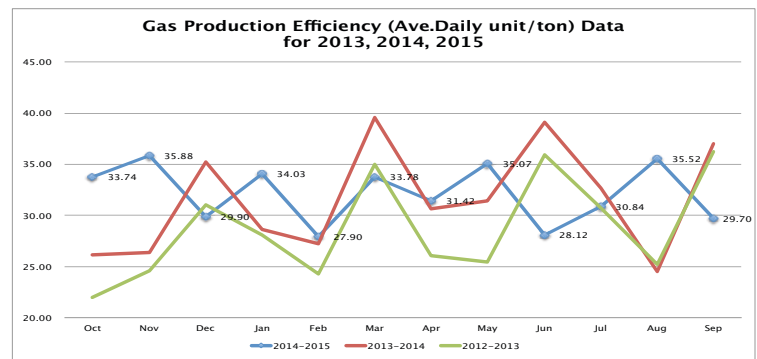

Fig. 5. Gas production efficiency from 20132015

\subsection{Cost saving, investment and payback}

The use of variable speed drive gave a considerable energy savings which when translated to cost is worth a fortune. The payback period being 3.5 years from installation period and investment cost are as follows; Energy Saving (estimated 30\% Savings $42 \mathrm{~Hz}$ ):

Cost Saving:

Investment Cost (Budget): $\quad 120,000 \mathrm{RM}$

ITA Savings addition:

$30,000 \mathrm{RM}$

Payback:

3.5 years

Annual Savings in $\mathrm{CO}_{2}$ Emission: 78 Tonnes of $\mathrm{CO}_{2}$

\subsection{Shared savings model}

Energy Saving (estimated 30\% Savings 42Hz):

Cost Saving: $\quad 36,000 \mathrm{RM} /$ year

Investment Cost: 0 RM

Maintenance Cost: 0 RM

Shared Savings: $\quad 20 \%$ FNDM

$$
\begin{aligned}
& \text { 7,200 RM/year } \\
& 80 \% \mathrm{ATECH} \\
& 28,800 \mathrm{RM} / \text { year }
\end{aligned}
$$

Duration: 5 years

Annual Savings in $\mathrm{CO}_{2}$ Emission: 83 Tonnes of $\mathrm{CO}_{2}$ Evaluations done by two companies reveals $80 \%$ cost savings by ATECH and $20 \%$ savings by FNDM. Up to 83 tonnes of carbon (iv) oxide was saved on annual basis thereby reducing environmental pollution.

\section{Conclusion}

Increased industrial growth has attracted increased energy demands from industrial systems. Energy production when optimally utilized indirectly affects the unit prices of finished products. Energy audit of energy consuming subsystems in a manufacturing 
system is of high necessity for increased profitability of the business. Variable speed drives on cooling towers triggered by varying wet bulb temperature readings is recommended in cooling tower systems. Energy supply from national grid decreases over the years with fossil fuels taking the market. Smart systems are recommended for high energy consuming equipment for minimal energy consumption.

\section{Acknowledgement}

This paper was supported by the Internal Grant of the University Malaysia Pahang (RDU: 160393) and Fundamental Research Grant Scheme (FRGS) grant of Malaysian Ministry of Higher Education (RDU140109).

\section{References}

[1] M.S. Bhatt, Appl. Therm. Eng. 20, 297-307 (2000)

[2] D.Y.L. Chan, J. Energy Policy. 35, 202-209 (2007)
[3] J. Facao, A.C. Oliveira, Appl. Therm. Eng. 20, 1225-1236 (2000)

[4] B.B. Ekici, U.T. Aksoy, Adv Eng Softw. 40, 356-362 (2008)

[5] EERE. U.S. Department of Energy (2011)

[6] P. Rai, I.A. Khan, International Analysis of Cooling Tower. 2, 96-102 (2016)

[7] BEE. Bureau of Energy Efficiency (2013)

[8] S. Arunkumar, D.B. Sivakumar, T. Senthikumar, Int. J. Eng. Sci. Comput. 6, 53595362 (2016)

[9] Z.K. Morvay, D.D. Gvozdenac, Appl. Ind. Energ. Environ. Manage. (2010)

[10] G.E.D Plessis, L. Leinbenberg, E.H. Matthews, Appl. Energ. 111, 16-27 (2013)

[11] A. Oumer, S. M. Atnaw, J. K. Cheng, L. Singh, Mater. Sci. Eng. (2016) 